Does EU Public Support to Firm Investments Boost High Quality Jobs? Evidence from Linked Employer-Employee Microdata and Natural-Experiment Conditions Daniele Bondonio Teresa Farinha Fernandes Ricardo Paes Mamede

Setembro 2016 WP n. ${ }^{\circ} 2016 / 01$ 


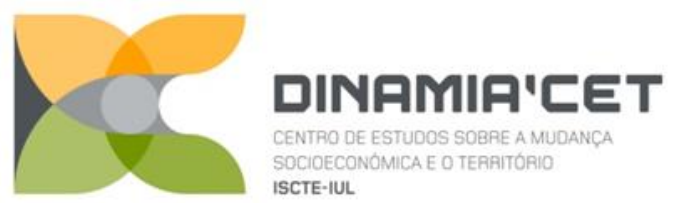

\title{
Does EU Public Support to Firm Investments Boost High Quality Jobs? \\ Evidence from Linked Employer-Employee Microdata and
} Natural-Experiment Conditions

\author{
Daniele Bondonio * \\ Teresa Farinha Fernandes ** \\ Ricardo Paes Mamede ***
}

WP n. ${ }^{\circ} 2016 / 01$

DOI: $10.15847 /$ dinamiacet-iul.wp.2016.01

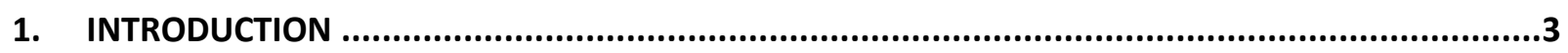

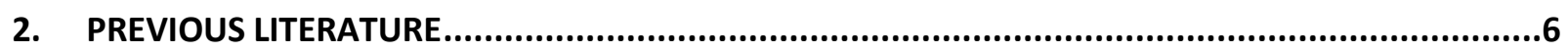

3. THE POE/PRIME PROGRAMME, DATA AND DESCRIPTIVE STATISTICS ...................................

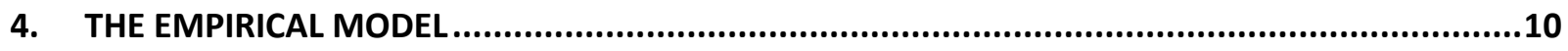

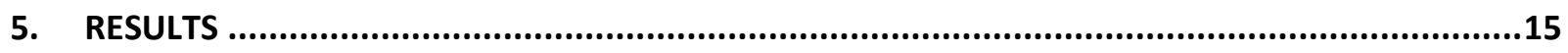

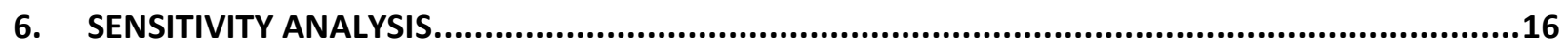

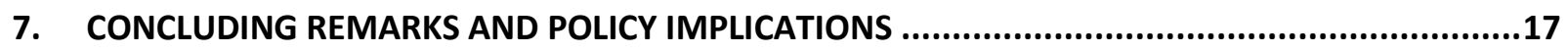

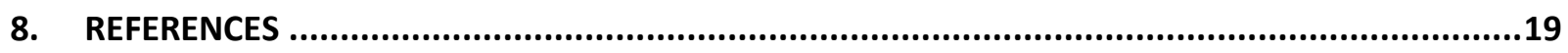

* University of Piemonte Orientale (IT) and The Ohio State University. Via Cavour 84, 15100 Alessandria (Italy). Phone. (+39) 131-283-712. Fax: (+39) 131-283-704. E-mail: daniele.bondonio@uniupo.it.

** Utrecht University (NL). Heidelberglaan 2, 3584 CS Utrecht (Netherlands). Phone (+351) 920354880. E-mail: t.farinhafernandes@uu.nl

*** Instituto Universitário de Lisboa (ISCTE-IUL), DINÂMIA'CET - IUL, Lisboa, Portugal. Corresponding author. ISCTE - IUL, Av. Forças Armadas. 1649-026 Lisboa, Portugal. E-mail: ricardo.mamede@iscte.pt 


\title{
Does EU Public Support to Firm Investments Boost High Quality Jobs? Evidence from Linked Employer-Employee Microdata and
}

\section{Natural-Experiment Conditions}

\begin{abstract}
In this paper we estimate the impact on job quality of the direct support to firm- investment projects provided through the EU cohesion policy funds. We use linked employer-employee micro-data, from administrative sources, that cover the universe of Portuguese firms over the years 2000s. The analysis exploits the existence of natural experiment conditions in the form of treatment assignment procedures based on exogenous cut-offs in the ranking of the applicant firms. Our preferred estimation strategy is a dynamic exact matching procedure that is combined with a difference-in-difference scheme to mimic a block-randomised pretest-posttest design. The procedure is adopted separately for each of the successive cohorts of applicants and solves the small sample issues that would be encountered with a multipleranking regression discontinuity design. Our results indicate that the firm-level support co-funded by EU structural funds in Portugal has contributed to improving job quality compared to the counterfactual scenario of no public support, with each treated firm creating on average 4.9 additional standard-workingtime jobs, 2.9 skilled jobs, and 2.0 permanent contract jobs. We also estimate that the average remuneration per hour in treated firms is $€ 2.2$ higher than in similar non-treated applicant firms. These results are adequately robust to a wide range of sensitivity analyses and bear some relevant policy implications for the EU.
\end{abstract}

JEL CLASSIFICATION: O1; R5; C23

KEYWORDS: Enterprise support programs, Counterfactual impact evaluation, Job-Quality, EU Cohesion Policy. 


\section{INTRODUCTION}

The reference to job quality as a main policy goal became a common feature in the European Union's (EU) strategic documents from the adoption of the Lisbon Agenda in 2000 (European Commission, 2008) ${ }^{1}$. However, do EU-funded policies contribute to improve the quality of jobs in the beneficiary countries and regions? Which dimensions of job quality are mostly affected by these policies? In this paper we provide answers to these questions, focusing on the impact of firm incentives funded by EU Cohesion Policy in Portugal.

Public support to firm investment, especially Small and Medium Sized companies (SMEs), is one of the main mechanisms through which the EU promotes socioeconomic convergence among EU regions. Under the current programming period (2014-2020), the European Commission has allocated around 20\% of the European Regional Development Fund (ERDF) - $€ 57$ billion - to supporting SME investment in competitiveness, research and innovation, the low-carbon economy and information and communication technologies ${ }^{2}$. The total amount of funds dedicated to these domains has been increasing over the years, as regional policy priorities shift away from investment in hard infrastructure towards business support and innovation (European Commission, 2014).

Fostering the creation of durable and quality jobs, as a necessary condition for the economic convergence of disadvantaged regions, is one of the main goals of EU enterprise support mechanisms. The failure to create good quality jobs jeopardises the development prospects of less-developed regions for two reasons. First, because the expansion of low quality jobs increases the risk of outsourcing production activities to areas with lower wages. Second, because the limited availability of high-quality jobs fosters the outflow of human capital to the more advanced regions. In this regard, improving job opportunities in disadvantaged regions, both quantitatively and qualitatively, is a main expected benefit of regional policies (Bartik, 2012) and one of the main goals of the EU Cohesion Policy. Moreover, boosting high-quality jobs is a crucial goal for enterprise support schemes in economically disadvantaged regions also in order to generate a demand-side complement of education and training policies aimed at increasing the supply of skilled labour.

For all of the above reasons, providing EU policy makers with reliable empirical evidence on the job-quality impact of firm-level cohesion policy support is of crucial importance. Producing such

\footnotetext{
${ }^{1}$ The increased emphasis on job quality is not exclusive to the EU. Several international organisations advocate the implementation of policy action to address the deleterious impacts of low quality employment on individual well-being and social inclusion (e.g., International Labour Organization, 2014; World Bank, 2013).

2 http://ec.europa.eu/regional policy/en/policy/themes/sme-competitiveness/
}

DINÂMIA'CET - IUL, Centro de Estudos sobre a Mudança Socioeconómica e o Território ISCTE-IUL - Av. das Forças Armadas, 1649-026 Lisboa, PORTUGAL

Tel. 210464031 - Extensão 293100 E-mail: dinamia@iscte.pt http://dinamiacet.iscte-iul.pt/ 
empirical evidence, however, is not an easy task for the following reasons: measuring job quality outcomes requires the rare availability of linked employer-employee micro-data merged with complete programme activity data; the existence of unobserved additional sources of public support generates potentially serious treatment measurement errors; firms self-select into the programme often without exogenous excluding restrictions (making it hard to control for unobservable differences between the treatment and the comparison group); it is often difficult to determine the exact place in time in which the treatment occurs and the period in which to measure the observable outcomes related to the supported investment.

Due to such difficulties, to the best of our knowledge, no reliable empirical evidence has yet been produced on the job quality impact of enterprise support programmes in the EU. This paper aims at filling the gap in the literature by providing robust counterfactual impact estimates on the following job-quality outcomes: number of jobs with standard working hours; jobs with high skill requirements; jobs with permanent contracts; and level of hourly remuneration.

Our analysis focuses on the direct firm-level support schemes offered by a large Operational Programme (the "Programme for the Modernisation of the Economy", or, POE/PRIME) implemented in Portugal over the 2000s and co-funded by the European Regional Development Fund (Third Community Support Framework). We merged the programme activity data from POE/PRIME with the linked employer-employee data collected yearly by the Portuguese Ministry of Employment and Social Solidarity on a compulsory basis. The resulting database offers ideal impact identification conditions to investigate the effects of EU firm support interventions on job quality because of the following three reasons.

First, the POE/PRIME programme has been a very prominent EU cohesion policy intervention, with a total budget of nearly $€ 8.3$ billion, financed in approximately equal parts by private and public sources (about $70 \%$ of the latter came from the European Regional Development Fund). The POE/PRIME's direct support to firms represented nearly $3 / 4$ of the total public funds of the programme and it was implemented through several policy schemes that represented by far the most prominent source of public aids (in terms of both the amount of funds and number of beneficiaries) for the Portuguese firms in the 2000-2006 programming period. These circumstances ensure a large external validity to the analysis and avoid the treatment contamination issues that would derive from the concurring presence of other policy interventions.

Second, the linked employer-employee administrative data used in the analysis is virtually free of the many attrition bias and measurement error limitations that plague the firm-level balance sheet data that is very often used in the evaluation of firm-support programmes.

DINÂMIA'CET - IUL, Centro de Estudos sobre a Mudança Socioeconómica e o Território ISCTE-IUL - Av. das Forças Armadas, 1649-026 Lisboa, PORTUGAL

Tel. 210464031 - Extensão 293100 E-mail: dinamia@iscte.pt http://dinamiacet.iscte-iul.pt/ 


\section{Does EU Public Support to Firm Investments Boost High Quality Jobs? Evidence from Linked Employer-Employee Microdata and Natural-Experiment Conditions}

Third, the programme was administered through a series of different calls for applications in which the treatment assignment occurred based on natural experiment conditions in the form of cut-off points in the rankings of applicants. Within our period of observation, 2003-2006, such cut-off points were based on application scores that did not reflect any major determinants of the future job-quality outcomes of the firms. This circumstance yields a natural experiment scenario in which the cut-offs in the application scores determine a treatment assignment process that mimics that of a randomised experiment for a large number of applicant firms.

Our preferred estimation strategy is aimed to fully exploit these desirable natural experiment conditions. This is done through a dynamic exact matching procedure that is implemented in combination with a difference in difference scheme and is adopted for each of the successive cohorts of applicant firms from the different calls. As discussed later in this paper, this procedure mimics the features of a pre-testpost-test block-randomisation design and it is preferred to a multiple ranking RDD design because of the potentially relevant unbalancing issues deriving from the small samples of applicants in the neighbourhood of the cut-off points.

The results of our analysis indicate that the firm-level support co-funded by EU structural funds in Portugal have contributed to improving several dimensions of job quality, compared to a counterfactual scenario of no public support. These results are robust to replicating the analysis with an extensive sensitivity analysis.

The remainder of this paper is organised as follows. Section 2 provides a brief survey of the related literature. Section 3 describes in greater detail the policy mechanisms under analysis, the data and some descriptive statistics. Section 4 discusses the identification problem and our preferred estimation model. Section 5 presents the main results and section 6 the sensitivity analysis. Section 7 concludes, discussing the policy implications of our study.

DINÂMIA'CET - IUL, Centro de Estudos sobre a Mudança Socioeconómica e o Território 


\section{PREVIOUS LITERATURE}

This paper is related to two main strands of literature. The first deals with the impact of firm-level public subsidies on firms' employment growth in Europe. This literature is rather diverse with regard to the geographical and time scopes, and the empirical modelling strategies used in the analysis. For example, Bondonio \& Greenbaum (2006) implemented a parametric conditional difference-in-differences model to calculate the employment impact of EU funded business incentives in northern and central Italy during the late 1990s; Bronzini \& de Blasio (2006) also adopt a difference-in-differences framework to analyse the effect of similar policies on firms located in southern Italian regions during the same period; the same policies were more recently investigated by Bernini \& Pellegrini (2011) using a combination of matching methods with difference-in-differences, and extending the analysis to the mid-2000s; Criscuolo et al. (2012) studied the effects of the Regional Selective Assistance to firms in the UK, from the mid-1980s to the mid-2000s, using a combination of instrumental variables and firm-level fixed-effects; Bia \& Mattei (2012) apply propensity score matching adjusting for differences in a set of observed pre-treatment variables to assess the employment impact of financial aid attributed to enterprises located in the Italian region of Piedmont in the early 2000s; Koski \& Pajarinen (2013) study the effect of investment support and other subsidies granted to SMEs in Finland during the 2000s, applying both an instrumental variables approach and difference-in-differences; finally, Cerqua \& Pellegrini (2014) reassess the same enterprise support mechanism analysed in Bronzini \& de Blasio (2006) and Bernini \& Pellegrini (2011), exploiting the discontinuities in the policy assignment process in order to apply a regression discontinuity design (using non-subsidised applicant firms as a control group).

The aforementioned studies have in common the focus on the impact of investment support mechanisms on employment growth at firm level in European regions. Although they differ in the scope of analysis and in the methods used, these studies converge in the conclusion that direct support to firm investment has a positive impact on employment growth at firm level. However, they do not provide any empirical evidence of direct impact on the quality of jobs created as a result of the policy intervention. Our paper contributes to this strand of literature in three ways: first, it adds to existing evidence by analysing the impact of EU funded support to firm investment in the case of Portugal; second, it addresses most of the methodological problems that are commonly found in attempts to estimate the impact of public support on firms' performance exploiting desirable natural experiment conditions and the availability of reliable linked employer-employee data without attrition bias and measurement error limitations; finally, it provides empirical evidence on the job quality impact of these policies, which has been absent in the literature.

DINÂMIA'CET - IUL, Centro de Estudos sobre a Mudança Socioeconómica e o Território ISCTE-IUL - Av. das Forças Armadas, 1649-026 Lisboa, PORTUGAL

Tel. 210464031 - Extensão 293100 E-mail: dinamia@iscte.pt http://dinamiacet.iscte-iul.pt/ 
The second strand of literature that is related to this paper refers to the analysis of job quality trends in the last decades. A number of studies have shown that work intensity and work stress increased in several countries and regions during the 1990s and the 2000s, with deleterious consequences for individual wellbeing and social inclusion (e.g., Clark, 2005; Green, 2006, 2008; Olsen, Kalleberg, \& Nesheim, 2010). In contrast, high job quality has been shown to increase worker motivation, customer loyalty and productivity, to lower absenteeism and turnover rates (Warr, 1999; Harter, Schmidt, \& Keyes, 2003), and to spur improvements in organisation performance and profitability (Boxall \& Macky, 2009; Kaufman, 2010). All these findings help to explain the growing concern with job quality as an important policy outcome to be considered. According to the International Labour Organization (2014) and the World Bank (2013), public policies can influence the quality of work and employment in several ways. By establishing and enforcing labour market regulations, governments can affect payments, entitlements, working conditions, and job security. Governments can also exert influence on social dialogue, enhancing the chances of achieving higher work standards through collective bargaining and agreements between trade unions and employers' representatives. Public policy interventions can also foster job quality at the firm level, either through employment subsidies, or through enterprise support mechanisms. Our paper adds to this job-quality literature by providing evidence on the impact of the latter type of policy interventions.

\section{THE POE/PRIME PROGRAMME, DATA AND DESCRIPTIVE STATISTICS}

The firm-level public support mechanisms exploited in our analysis are those of the main Operational Programme of the Third Community Support Framework in Portugal (i.e. the POE/PRIME ${ }^{3}$ programme) that was co-funded in by the EU Cohesion Policy funds in the programming period 2000-2006. POE/PRIME was a large and comprehensive policy intervention, involving nearly $€ 8.3 \mathrm{~b}$, financed in approximately equal parts by private and public sources (about $70 \%$ of the latter came from the ERDF). The Programme included not only support schemes that had firms as direct beneficiaries, but also policy interventions aiming to promote the modernisation of the Portuguese economy by fostering the development of the context in which firms operate (including professional training, financial engineering, technology transfer, business networking, etc.).

3 The Programme was originally called POE (Operational Programme for the Economy) and was lately renamed PRIME (Programme for the Modernisation of the Economy).

DINÂMIA'CET - IUL, Centro de Estudos sobre a Mudança Socioeconómica e o Território ISCTE-IUL - Av. das Forças Armadas, 1649-026 Lisboa, PORTUGAL

Tel. 210464031 - Extensão 293100 E-mail: dinamia@iscte.pt http://dinamiacet.iscte-iul.pt/ 
POE/PRIME's direct support to firms, which represented nearly $3 / 4$ of the Programme's public funding, included several schemes targeting specific types of investment and/or types of firm. These schemes differed in some technical-administrative aspects such as: the minimum amount of investment, the type of admissible investment ${ }^{4}$, the intensity of public support and the nature of the incentive (soft loan, grant, mixed). In practice, however, the relevant differences between these schemes regarded primarily the characteristics of the admissible beneficiary firms in terms of size class and industry. Moreover, all POE/PRIME firm-level support schemes were subjected to similar sets of programme application rules and shared the same overall policy goals of enhancing the competitiveness of Portuguese SMEs through investments in innovation and internationalisation. Therefore, all POE/PRIME direct support schemes are pooled together in the present study.

Even though POE/PRIME was not the only firm support programme in Portugal during the period under analysis, it was by far the most relevant one, both in terms of public funds and number of beneficiaries. Less than $1 \%$ of the firms supported under these schemes received some kind of direct support from other programmes. These circumstances ensure a large external validity on the analysis and virtually eliminate the treatment contamination threats that may derive from the concurring presence of other public policies.

The different POE/PRIME direct support schemes were administered through an application process that sorted the applicants into a treated and a non-treated group based on two indicators described more in the next section of the paper. The presence of such non-treated applicants enables us to compare beneficiaries with nontreated firms that shared the same desire to invest. This is crucial to control for many important unobservable characteristics of the firms such as the position in their investment cycle, risk aversion, and management style. The POE/PRIME programme activity data at our disposal covers all the investment projects submitted by the applicant firms, with information on: application date, total value of the investment project, the amount of the programme support and the timing in which the supported investment took place (if applicable). Such precise information on the timing in which the supported investment occurred, enabling the beneficiaries to be sorted into different cohorts based on the exact dates of their investment project. This feature strongly reduces the measurement errors than can arise when timing the correct moment in which to measure the job-quality outcomes and the pre-intervention control variables.

\footnotetext{
${ }^{4} \mathrm{~A}$ broad distinction can be made between two main groups of support scheme: those focusing on investments in physical capital (which constitute the bulk of the programme, representing nearly $90 \%$ of the projects and $80 \%$ of the funds), and those fostering the upgrading of SME strategies (including dimensions such as R\&D activities, IPR, energy efficiency, etc.).
}

DINÂMIA'CET - IUL, Centro de Estudos sobre a Mudança Socioeconómica e o Território 
The linked-employer-employee-data (LEED) used in the analysis stems from an administrative database maintained by the Portuguese Ministry of Employment and Social Solidarity. Such database includes information related to both the characteristics of firms (total employment, industry classification, geographic location, legal status, ownership, number of plants, etc.) and their employees (sex, date of birth, educational background, professional category, type of contract, etc.). All information included in the database is compulsorily submitted on yearly basis by each and every firm operating in Portugal. For this reason, the database is virtually free of the many attrition bias and measurement error limitations that plague the employment information extracted from the balance sheet databases (e.g. the Bureau Van Dick's Amadeus) often used in the evaluation of firm-support programmes.

We merged the LEED data, made available by the Portuguese Ministry of Employment and Social Solidarity, with the POE/PRIME programme activity data, using the firms' National Tax Code as the common firm-identifier ${ }^{5}$. Although the POE/PRIME programme was active between 2000 and 2009, we restrict our analysis to the years 2003-2006 because only for such period we had at our disposal both the LEED and the program activity data that grants the full coverage of both the pre- and the posttreatment periods considered in our estimation model. During the 2003-2006 period, the POE/PRIME programme was administered through 9 different calls for applications, with an average presence of about 95 treated applicants and 70 non-treated applicants in each of these calls.

Table 1 summarises the total number of treated and non-treated applicants sorted by year of application (t).

Table 1: $\mathrm{N}^{\mathrm{o}}$ of treated and non-treated applicant firms by year of application $(t)$

\begin{tabular}{cccc}
\hline Year $(\mathbf{t})$ & $\begin{array}{c}\text { Treated } \\
\text { applicants }\end{array}$ & $\begin{array}{c}\text { Non-treated } \\
\text { applicants }\end{array}$ & Total \\
\hline \hline $\mathbf{2 0 0 3}$ & 187 & 128 & 315 \\
$\mathbf{2 0 0 4}$ & 58 & 104 & 162 \\
$\mathbf{2 0 0 5}$ & 99 & 27 & 126 \\
$\mathbf{2 0 0 6}$ & 515 & 375 & 890 \\
Total & 859 & 634 & 1493 \\
\hline
\end{tabular}

5 The two databases were made available upon request, exclusively for the purpose of assessing the impact of the policy mechanisms under analysis.

DINÂMIA'CET - IUL, Centro de Estudos sobre a Mudança Socioeconómica e o Território ISCTE-IUL - Av. das Forças Armadas, 1649-026 Lisboa, PORTUGAL

Tel. 210464031 - Extensão 293100 E-mail: dinamia@iscte.pt http://dinamiacet.iscte-iul.pt/ 
Table 2 shows the descriptive statistics of the pre-post-treatment $[(t+3)-(t-1)]$ changes of the outcome variables, sorted by treated and non-treated applicant firms.

Table 2: Average change (per firm) of the outcome variables between the pre (t-1) and post $(t+3)$ intervention times

\begin{tabular}{|c|c|c|}
\hline \multirow[b]{2}{*}{ Outcome variable $\mathbf{Y}$} & \multicolumn{2}{|c|}{$\Delta Y(t+3)-(t-1)$} \\
\hline & $\begin{array}{c}\text { Treated } \\
\text { applicants }\end{array}$ & $\begin{array}{c}\text { Non treated } \\
\text { applicants }\end{array}$ \\
\hline Jobs with standard working hours ( $1=1$ job $)$ & 2.9 & -1.7 \\
\hline Skilled jobs (1=1 job) & 2.9 & 0.0 \\
\hline Jobs with permanent contracts $(1=1$ job $)$ & 2.3 & -0.3 \\
\hline Average hourly remuneration ( $1=1$ euro) & 2.0 & 0.3 \\
\hline
\end{tabular}

\section{THE EMPIRICAL MODEL}

Our estimation strategy is designed fully to explore the presence of the different multiple consecutive calls for applications under which the POE/PRIME programme was administered. In these calls, applicants were ranked based on an application score, and the treatment assignment was determined by cut-off points in the ranking of the application scores. The operational rules for assigning the application score varied along the different calls for applications. In our 2003-2006 period of observation, the score was based solely on two factors: a) an indicator that measures the present value (in percentage of the total investment value) of the sum of the projected taxable profits, the additional labour costs and the interests paid to financial institutions for the part of the investment not covered by the programme funds; $b$ ) an indicator of financial autonomy, in terms of the ratio between the firm's equity and its total assets, intended to capture the projected risk of failure of the firm.

Such operational rules yielded application scores that did not reflect major factors directly correlated with the future job-quality dynamics of the applicant firms. In addition, all the information on the investment project submitted by the applicant firms was predominantly prepared by external consultants who used all the degrees of discretionality allowed by the programme rules to include in the application packages the figures that in their judgement would make it more likely to produce a high application score. Thus, the resulting rankings were significantly affected by such degrees of discretionality used by the external consultants.

DINÂMIA'CET - IUL, Centro de Estudos sobre a Mudança Socioeconómica e o Território ISCTE-IUL - Av. das Forças Armadas, 1649-026 Lisboa, PORTUGAL

Tel. 210464031 - Extensão 293100 E-mail: dinamia@iscte.pt http://dinamiacet.iscte-iul.pt/ 
Because of the presence of cut-off points $k$ in the ranking of applicants, it is well established in the literature (e.g. Hahn et al. 2001, Battistin and Rettore 2008, Lee and Lemieux 2010) that a sharp regression discontinuity design (RDD) can exploit the presence of firms in the neighbourhood of $k$ for which their treatment status mimics the result of a block randomisation based on the values of the forcing variable (i.e. the application score). However, when the forcing variable has very little or no influence on the outcome variable $\mathrm{Y}$ of the analysis, as in our case, the treatment assignment process mimics an actual randomisation also for firms further away from $k$. This is because, in such cases, the application score represents a variable that affects solely the treatment assignment and not the outcome variable of the analysis. This is a natural experiment scenario in which the selection into treatment mimics the features of a randomised experiment for all applicant firms, or, in other words, the neighbourhoods of $\mathrm{k}$ in which the randomised assignment conditions hold are extended to include all applicant firms.

In such scenario, adopting a difference in difference scheme to compare the pre-post treatment change of job-quality outcomes between the treated- and non-treated applicant firms within each same call for applications would be the equivalent of applying a pre-test-post-test design in the context of an actual randomised experiment. The different local impact estimates deriving from the multiple rankings of the POE/PRIME programme could then be aggregated to yield the average treatment effect on the treated (ATT) parameter of interest (as done in Cerqua and Pellegrini (2014) in the context of programme data with a similar yearly sequence of calls for applications). In the case of the POE/PRIME programme, however, the number of applicants included in each call for application is not large enough to guarantee that the pseudo-randomisation conditions deriving from the programme procedure achieve a full balancing of the crucial pre-application firm characteristics that may have an influence on future jobquality outcomes.

These characteristics are: industrial sector, size class, regional location, age of the firm, preapplication employment growth-trend and pre-application job-quality level. For all of these covariates, the degree of unbalancing across treated and non-treated applicants does not display a stable pattern across the different calls for applications in favour of any of the two groups of firms, but in many cases would be significant enough to jeopardise the unbiasedness of the estimates. Such unbalancing is similar to the issue that would arise from using small sample sizes in actual randomised experiments. For example, Kernan et al. (1999) show that even with pure random assignment the probability that the treatment and

DINÂMIA'CET - IUL, Centro de Estudos sobre a Mudança Socioeconómica e o Território 
control group will differ significantly along some important dimensions becomes very relevant with sample sizes smaller than 200 units $^{6}$.

In such small-sample experiments, it is well established in the literature (see for example the review by Bruhm and Mckenzie, 2008) that one viable solution for preventing unbalancing is to adopt a block randomisation design based on the major confounding factors that may affect the outcome variable of the analysis. Instead, applying an RDD approach to estimate the local ATTs for each ranking of the POE/PRIME applicants would further exacerbate the unbalancing of the crucial covariates. This is because in the neighbourhoods of the cut-off $k$ the sample size of the applicant firms would be further diminished. As previously discussed, contrary to the standard discontinuity design set-ups, in the case of the POE/PRIME programme, the forcing variable does not capture the relevant covariates that have to be controlled for. As a consequence, comparing treated and non-treated applicants at the neighbourhood of the cut-off $k$ would be inefficient and would not guarantee an adequate balancing of the relevant covariates in the presence of small sample sizes.

For these reasons, the preferred empirical strategy that we use for the analysis has analogies with the block randomisation design that would be used in the context of repeated small sample experiments. In order to best explore the presence of the multiple rankings of applicants with randomised-like treatment assignments, we implemented the equivalent of a pre-test-post-test design in terms of a DD scheme that compares the pre-post application job quality outcome change of the treated and non-treated applicants selected through an exact matching procedure implemented separately within each yearly round of calls for applications. Such an estimator is quite a novelty in evaluating firm-level support interventions, with a similar approach being implemented, to the best of our knowledge, only in Bondonio \& Martini (2012). Dynamic statistical matching for successive cohorts of treated units, however, are well established estimation models in the field of evaluating active labour market policies (e.g., Sianesi, 2004) and they have also been recently applied to county-level impact estimates (e.g., Greenbaum \& Bondonio, 2014).

Our DD estimator, implemented through a dynamic exact matching procedure for each successive cohort of yearly calls for applications, yields a local ATT estimate for each cell of applicants within each cohort of calls for applications. The different cell-specific local ATTs are then successively aggregated into local impact estimates at the level of the yearly calls for applications, while the global ATTs of

${ }^{6}$ Kernan et al. (1999) show that when considering a binary covariate present in 30 percent of the sample, the probability that the treatment and control groups will differ by more than 10 percent is $38 \%$ with a sample size of 50 units, 27\% with 100 units, 9\% with 200 units, and 2\% with 400 units.

DINÂMIA'CET - IUL, Centro de Estudos sobre a Mudança Socioeconómica e o Território 
interest are finally estimated through aggregating the local impact estimates across the different yearly cohorts of calls.

The exact-matching stratification procedure that we use within our empirical strategy is preferable to a one-dimensional matching based on a single propensity score (PS) variable because a good part of our covariates are categorical by nature (i.e. firms' industrial sector, regional location), while others represent risk-factors for selection bias mainly across discrete intervals (e.g. the pre-application size class of the firms and the distinction between relatively new firms versus incumbent firms at the time of application). Moreover, each of these covariates can have an equally relevant potential impact on the future determinations of the outcome variable. In these circumstances, as also discussed elsewhere in the literature (e.g., Ho, Imai, King, \& Stuart, 2007; King, Nielsen, Coberley, \& Pope, 2011), a onedimensional matching based on a PS variable can disguise some admissible degree of mismatching on single covariates ${ }^{7}$. Such mismatching can lead to severe bias on the impact estimates, and for this reason it is recommended (Ho, Imai, King, \& Stuart, 2007) that absolute constraints are placed in the matching procedures to guarantee the perfect balancing of the covariates with the highest rank of importance for the future determination of the outcome variable. Because of these considerations, the relatively small number of our equally-important covariates is conducive to adopting an exact matching stratification of the applicants. Such a procedure guarantees both a limited loss of external validity (with only a limited number of treated applicants outside the common support) and the avoidance of any hidden residual degree of unbalance on some single covariates that could be conducive to selection bias in the impact estimates.

In detail, our preferred estimation model can be summarised through the following steps:

i) All firms contained in the POE/PRIME-LEED database are sorted into applicants and non-applicant groups. The applicant group is further divided into successive cohorts $(p)$ of applicants based on their year of application.

ii) To fully explore the natural experiment conditions involved in programme procedures, the non-applicant firms are dropped from the analysis.

\footnotetext{
7 This is because the balancing property of the propensity score (PS) is satisfied when for the single covariates nonstatistically significant differences are detectable between the treated and comparison units, conditional to similar (PS). However, hidden behind the non-statistically significance there could be unbalancing of single covariates that might induce large selection bias in the impact estimates if such covariates are of high rank of importance for the future determination of the outcome variable.
}

DINÂMIA'CET - IUL, Centro de Estudos sobre a Mudança Socioeconómica e o Território ISCTE-IUL - Av. das Forças Armadas, 1649-026 Lisboa, PORTUGAL

Tel. 210464031 - Extensão 293100 E-mail: dinamia@iscte.pt http://dinamiacet.iscte-iul.pt/ 


\section{Does EU Public Support to Firm Investments Boost High Quality Jobs? Evidence from Linked Employer-Employee Microdata and Natural-Experiment Conditions}

iii) Within each cohort $(p)$ of applicants, we coarsen the relevant covariates (X) into a number of discrete categories. These categories represent the distinct firm-level characteristics that in the years before the period of observation of our analysis are shown in the Portuguese LEED database to correlate with different levels of the job-quality outcomes that we consider in the analysis:

a. The industrial sector is coarsened into: low-tech industries; high-tech industries; construction; trade; accommodation and food service activities; knowledge-intensive market services;

b. Pre-application firm size: 1-4 employees; 5-9; 10-19; 20-49; 50-99; 100-250;

c. Age of the firm at the time of the application: 1-4 years of age; 5 years or more;

d. Geographic location: Norte; Algarve; Centro; Lisboa; Alentejo; Açores; Madeira; Inter-regional ${ }^{8}$;

e. Pre-application growth-trend of employment [in terms of employment change between (t-3) and (t-1), with $\mathrm{t}$ being the application year]: workforce decrease; constant; decrease; firm not in existence at t-3;

f. The firms' pre-application level of the job-quality outcome (Y) used in the analysis is coarsened into two categories: one below and one above the average of the firms within the same sector and size class.

iv) Separately for each cohort $(p)$ of applicants sharing the same application year, we match the treated with the non-treated applicants with the same exact values of the coarsened controls (X). The results of this matching procedure is a number of cells $(c)$ with identical categories of the controls $(\mathrm{X})$.

v) Local ATTs for each cell $(c)$ of identical treated and non-treated matched applicants sharing a same application year $(p)$ are estimated through the following DD estimator:

$$
\tau_{p c}^{D D}=E\left[Y_{t+3}^{1}-Y_{t-1}^{0} \mid T_{c}=1, X, p\right]-E\left[Y_{t+3}^{0}-Y_{t-1}^{0} \mid T_{c}=0, X, p\right] .
$$

\footnotetext{
${ }^{8}$ The Inter-regional category is applied to all firms that do not sell the majority of their products and services on a regional market.
}

DINÂMIA'CET - IUL, Centro de Estudos sobre a Mudança Socioeconómica e o Território ISCTE-IUL - Av. das Forças Armadas, 1649-026 Lisboa, PORTUGAL

Tel. 210464031 - Extensão 293100 E-mail: dinamia@iscte.pt http://dinamiacet.iscte-iul.pt/ 
vi) Average ATTs for each cohort (p) of treated applicants sharing a same application year are estimated as the following weighted averages of the local $\tau_{p c}^{D D}$ :

$$
\tau_{\mathrm{p}}^{\mathrm{DD}}=\sum_{c}\left[\tau \mathrm{DD} \mathrm{pc}_{\mathrm{pc}} * W p_{c}\right]
$$

with weights $W p_{c}=\frac{N p_{c}}{\sum N p_{c}}$ computed as the number of treated firms in cell $(c)$ over the total number of treated firms in cohort $(p)$.

vii) Global ATTs, across all yearly cohorts of applicants are estimated as the weighted average of $\tau$ DDp, with weights proportional to the number of treated firms in each cohort $(p)$.

\section{RESULTS}

The impact estimates from our preferred estimation model described above are summarised in Table 3.

Table 3: ATT estimates from the Exact Matching specification on treated and non-treated applicants

\begin{tabular}{lcccc}
\hline \multicolumn{1}{c}{ Outcome variable (Y) } & $\begin{array}{c}\mathbf{N}^{\mathbf{0}} \\
\text { treated } \\
\text { firms }\end{array}$ & $\begin{array}{c}\mathbf{N}^{\mathbf{0}} \\
\text { non- } \\
\text { treated } \\
\text { firms }\end{array}$ & ATT & sd \\
\hline \hline Jobs with standard working hours (1=1 job) & 386 & 308 & $4.9 * *$ & 1.65 \\
Skilled jobs (1=1 job) & 385 & 320 & $2.9 * *$ & 1.41 \\
Permanent Jobs (1=1 job) & 389 & 311 & $2.0^{*}$ & 1.57 \\
$\begin{array}{l}\text { Avg. remuneration per hour } \\
\text { (1= 1 euro)) }\end{array}$ & 387 & 290 & $2.2 * *$ & 1.05 \\
\hline$* *=$ Statistically significant at 5\% level. & & & & \\
$*=$ Statistically significant at 10\% level. & & & &
\end{tabular}

The results from Table 3 indicate that the POE/PRIME programme co-funded by EU cohesion policy funds generated a growth in the number of jobs with standard working hours that is higher than the counterfactual trend of no public support by an average of 4.9 additional jobs per firm. Such a positive programme impact on job quality indicators is confirmed also for the number of skilled and permanent jobs (with an estimated growth impact of +2.9 skilled jobs and +2.0 permanent jobs per firm, compared to the counterfactual trend of no public support), and for the change in the average pay per hour (with an estimated growth impact of $+€ 2.20$ per hour, compared to the counterfactual trend of no public support). 


\section{SENSITIVITY ANALYSIS}

Our preferred estimation model maximises the controlling of selection bias in the impact estimates by excluding from the comparison group the firms that did not apply for the programme incentives. This exclusion is vital to fully explore the desirable natural experiment conditions arising from the programme treatment assignment procedures and to achieve the balancing of the important unobservable covariates captured by the decision to apply for the programme (e.g. the firms' positions in their investment cycles, risk aversion, and management style). Excluding non-applicant firms from the potential composition of the comparison groups, however, comes at a cost of modestly: A) decreasing the statistical efficiency and external validity of the impact estimates (due to the exclusion of some treated applicants that are outside the common support); B) reducing the possibility of achieving a stricter balancing of the observable covariates. The latter point is due to the fact that the sample size of the comparison groups formed by the non-treated applicants is smaller than that of the comparison groups drawn from the general population of non-treated firms. For this reason, a matching procedure based on non-treated applicants has to use coarser categorisations of some observable covariates (e.g. size class and age of the firms) than a matching that uses the general population of non-treated firms.

Because of such possible limitations A) and B), we tested the robustness of our results by replicating the analysis with three additional estimation models that enlarge the composition of the comparison group to include the non-applicant firms as well. These models are the following: a) The same preferred estimation procedure replicated on an enlarged comparison group that also includes all the non-applicant firms; b) A Propensity Score Matching - PSM - (radius) procedure based on the same categorical covariates of the preferred estimation model, but applied to the enlarged comparison group; c) A PSM (radius) procedure applied to the enlarged comparison group, but with continuous functional forms for the following control variables: firm size (number of employees); firm age (in years); preintervention growth trend (employment change); pre-intervention level of the outcome variable.

DINÂMIA'CET - IUL, Centro de Estudos sobre a Mudança Socioeconómica e o Território 
Table 4: Results from the sensitivity analysis - Comparison of ATT estimates from different estimation models

\begin{tabular}{|c|c|c|c|}
\hline Output variable $Y$ & $\begin{array}{c}\text { Exact } \\
\text { matching } \\
\text { (All firms) }\end{array}$ & $\begin{array}{c}\text { PSM- } \\
\text { categorical } \\
\text { controls } \\
\text { (All firms) }\end{array}$ & $\begin{array}{c}\text { PSM } \\
\text { continuous } \\
\text { controls } \\
\text { (All firms) }\end{array}$ \\
\hline Jobs with standard working hours (1=1 job) & $5.9 * * *$ & $5.8 * * *$ & $5.0 * * *$ \\
\hline (sd) & $(0.62)$ & $(\mathbf{0 . 1 4})$ & $(\mathbf{0 . 1 5})$ \\
\hline Skilled jobs (1=1 job) & $4.1 * * *$ & $3.9 * * *$ & $4.4 * * *$ \\
\hline (sd) & $(\mathbf{0 . 5 0 )}$ & $(\mathbf{0 . 1 3})$ & $(\mathbf{0 . 1 3})$ \\
\hline Permanent jobs $(1=1$ job $)$ & $4.3 * * *$ & $4.1 * * *$ & $3.2 * * *$ \\
\hline$(\mathbf{s d})$ & $(0.49)$ & $(\mathbf{0 . 1 3})$ & $(\mathbf{0 . 1 3})$ \\
\hline Avg. remuneration per hour $(1=1$ euro $)$ & $1.8 * * *$ & $\mathbf{0 . 0}$ & $\mathbf{0 . 0}$ \\
\hline (sd) & $(0.44)$ & $(\mathbf{0 . 0 3})$ & $(0.03)$ \\
\hline
\end{tabular}

The results from these three additional estimation models, summarised in Table 4, show a low volatility of the impact estimates across the different methodological options (with the only exception of the two PSM impact estimates on average hourly remuneration), confirming an overall adequate robustness for our findings.

\section{CONCLUDING REMARKS AND POLICY IMPLICATIONS}

In this paper we exploited the availability of linked employer-employee data and the presence of desirable natural experiment conditions offered by a large programme co-funded by the EU Cohesion Policy funds in Portugal (the POE/PRIME programme) to estimate the impact of firm investment support policies on a number of job quality outcomes. To the best of our knowledge, this is the first paper providing robust empirical evidence regarding the impact of EU-funded enterprise support policies on job-quality outcomes at firm level. The linked employer-employee data (LEED) that we use in the analysis, merged with the activity data from the POE/PRIME programme, offer ideal impact identification conditions for the following reasons. First, our LEED data come from administrative records that are free of the many attrition bias and measurement error limitations that plague the firm-level balance sheet data that are elsewhere commonly used in counterfactual evaluation of firm level support programmes. Second, the POE/PRIME programme activity data ensure an adequate external validity for the results and limit the treatment contamination issues deriving from the concurring presence of other policy interventions. This is because the POE/PRIME programme is a very prominent EU cohesion policy intervention, with a total

DINÂMIA'CET - IUL, Centro de Estudos sobre a Mudança Socioeconómica e o Território 
budget of nearly $€ 8.3$ billion (and direct support to firms that represented nearly $3 / 4$ of the programme's total public funds) and it was by far the most prominent source of support for Portuguese firms during our period of observation., the natural experiment conditions arising from the programme treatment assignment procedures ensure the possibility in the analysis of avoiding the selection bias issues that are commonly present when no exogenous treatment exclusions are in place.

Our results suggest that the POE/PRIME programme has contributed to improving job quality compared to the counterfactual scenario of no public support, with each treated firm creating on average 4.9 additional standard-working-time jobs, 2.9 skilled jobs, and 2.0 permanent contract jobs. We also estimate that the average remuneration per hour in treated firms is $€ 2.2$ higher than in similar non-treated applicant firms. These results come from a preferred estimation model that mimics a block-randomised pre-test-post-test design in the form of a dynamic exact matching procedure, combined with a difference in difference scheme that is adopted separately for each of the successive cohorts of applicant firms from the different calls. The results are also adequately robust to a wide sensitivity analysis in terms of using a different control group (the universe of all non-treated firms, instead of solely non-treated applicant firms) and using an alternative dynamic matching procedure (propensity score versus exact matching).

Although the scope of the analysis recommends some caution in extracting strong policy conclusions at the European level, our findings bear adequate external validity and have some noticeable implications that should be considered. First, they highlight the fact that increasing job quality is a policy goal that can be pursued through EU industrial policies in the form of enterprise support interventions (even if job-quality outcomes were not an explicit goal of these policies). Thus, our results indicate that industrial policies can have noticeable impacts on job-quality outcomes in the same vein as labour market regulations, social dialogue, and active labour market policies that were traditionally be regarded as the main instruments to achieve desirable job-quality outcomes (e.g., International Labour Organization, 2014; World Bank, 2013). Second, our results implicates that the regional policies that attempt to increase the endowment of human capital through individual-based policies (as opposed to place-based ones; e.g., Barca et al., 2012) - as is often the case with education and training policies - can be successfully complemented with policy instruments that aim to expand the demand for high quality labour. Such demand expansion can derive from policy interventions aimed at supporting firm-level investment projects that may increase the stock of more innovative and sophisticated production procedures and organizational schemes. These considerations are of particular relevance in the present times in which an increasing pressure is placed on the EU Cohesion Policy to effectively foster the creation of decent job opportunities in the less developed regions that have to deal with enduring high unemployment rates and slow economic growth.

DINÂMIA'CET - IUL, Centro de Estudos sobre a Mudança Socioeconómica e o Território ISCTE-IUL - Av. das Forças Armadas, 1649-026 Lisboa, PORTUGAL

Tel. 210464031 - Extensão 293100 E-mail: dinamia@iscte.pt http://dinamiacet.iscte-iul.pt/ 


\section{REFERENCES}

BARCA, F., McCann, P. \& Rodrìguez-Pose, A. (2012). The case for regional development intervention: place-based versus place-neutral approaches. Journal of Regional Science 52(1): 134-152.

BARTIK, T. J. (2012). The Future of State and Local Economic Development Policy: What Research Is Needed. Growth \& Change, 43(May), 545-562.

BATTISTIN, E., \& Rettore, E. (2008). Ineligibles and eligible non-participants as a double comparison group in regression-discontinuity designs. Journal of Econometrics, 142(2), 715-730.

BERNINI, C., \& Pellegrini, G. (2011). How are growth and productivity in private firms affected by public subsidy? Evidence from a regional policy. Regional Science and Urban Economics, 41(3), 253265. doi:10.1016/j.regsciurbeco.2011.01.005.

BIA, M., \& Mattei, A. (2012). Assessing the effect of the amount of financial aids to Piedmont firms using the generalized propensity score. Statistical Methods and Applications, 21(4), 485-516. doi:10.1007/s10260-012-0193-4.

BONDONIO, D., \& Greenbaum, R. T. (2006). Do Business Investment Incentives Promote Employment in Declining Areas? Evidence from EU Objective-2 Regions. European Urban and Regional Studies, 13(3), 225-244. doi:10.1177/0969776406065432.

BONDONIO, D., \& Martini, A. (2012). Counterfactual impact evaluation of cohesion policy: impact and cost-effectiveness of investment subsidies in Italy. Final Report to DG Regional Policy.

BOXALL, P., \& Macky, K. (2009). Research and theory on high-performance work systems: progressing the high-involvement stream. Human Resource Management Journal, 19(1), 3-23. doi:10.1111/j.17488583.2008.00082.x.

BRONZINI, R., \& de Blasio, G. (2006). Evaluating the impact of investment incentives: The case of Italy's Law 488/1992. Journal of Urban Economics, 60(2), 327-349. doi:10.1016/j.jue.2006.03.005.

BRUHN, M., \& McKenzie, D. J. (2008). "In Pursuit of Balance: Randomization in Practice in Development Economics", Unpublished Manuscript, World Bank.

DINÂMIA'CET - IUL, Centro de Estudos sobre a Mudança Socioeconómica e o Território 
BURGESS, J., \& Connell, J. (2008). Introduction to special issue. The International Journal of Human Resource Management, 19(3), 407-418. doi:10.1080/09585190801895494.

CERQUA, A., \& Pellegrini, G. (2014). Do subsidies to private capital boost firms' growth? A multiple regression discontinuity design approach. Journal of Public Economics, 109, 114-126. doi:10.1016/j.jpubeco.2013.11.005.

CLARK, A. (2005). What Makes a Good Job? Evidence from OECD Countries. In S. Bazen, C. Lucifora, \& W. Salverda (Eds.), Job Quality and Employer Behaviour (pp. 11-30). Basingstoke: Palgrave Macmillan.

CRISCUOLO, C., Martin, R., Overmann, H., \& Van Reenen, J. (2012). The Causal Effects of an Industrial Policy. NBER Working Paper Series, Working $\mathrm{Pa}$. Retrieved from http://www.nber.org/papers/w17842.

EUROPEAN COMMISSION. (2008). Employment in Europe 2008. Brussels: European Commission, Directorate-General for Employment, Social Affairs and Equal Opportunities.

EUROPEAN COMMISSION. (2014). Sixth report on economic, social and territorial cohesion: investment for jobs and growth - Promoting development and good governance in EU regions and cities. Brussels: European Commission, DG for Regional and Urban Policy and DG for Employment, Social Affairs and Inclusion.

GREEN, F. (2006). Demanding work: The paradox of job quality in the affluent economy. Princeton: Princeton University Press.

GREEN, F. (2008). Work effort and worker well-being in the age of affluence. In R. Burke \& C. L. Cooper (Eds.), The Long Work Hours Culture: Causes, Consequences and Choices (pp. 115-136). Bingley: Emerald Group Publishing.

GREENBAUM, R. T., \& Bondonio, D. (2014). Community Resilience to Rare Events: Using Dynamic Propensity Score Matching to Examine the Effects of Disasters. Paper Prepared for the 61st North American Meetings of the Regional Science Association International.

DINÂMIA'CET - IUL, Centro de Estudos sobre a Mudança Socioeconómica e o Território 
HAHN, J., Todd, P., \& Van der Klaauw, W. (2001). Identification and estimation of treatment effects with a regression-discontinuity design. Econometrica, 69(1), 201-209.

HARTER, J. K., Schmidt, F. L., \& Keyes, C. L. (2003). Well-being in the workplace and its relationship to business outcomes: A review of the Gallup studies. In C. L. Keyes \& J. Haidt (Eds.), Flourishing: Positive psychology and the life well-lived (pp. 205-224). Washington: American Psychological Association.

HO, D. E., Imai, K., King, G., \& Stuart, E. A. (2007). Matching as Nonparametric Preprocessing for Reducing Model Dependence in Parametric Causal Inference. Political Analysis, 15, 199-236. doi:10.1093/pan/mp1013.

IACUS, S. M., King, G., \& Porro, G. (2011). Causal Inference without Balance Checking: Coarsened Exact Matching. Political Analysis, 20(1), 1-24. doi:10.1093/pan/mpr013.

INTERNATIONAL LABOUR ORGANIZATION (2014). World of Work Report 2014. Developing with jobs. Geneva: ILO.

KAUFMAN, B. E. (2010). The Theoretical Foundation of Industrial Relations and Its Implications. Industrial and Labor Relations Review, 64(1), 74-108.

KERNAN, W. N., Viscoli, C. M., Makuch, R. W., Brass, L. M., \& Horwitz, R. I. (1999). Stratified randomization for clinical trials. Journal of clinical epidemiology, 52(1), 19-26.

KING, G., Nielsen, R., Coberley, C., \& Pope, J. E. (2011). Comparative Effectiveness of Matching Methods for Causal Inference. Working Paper.

KOSKI, H., \& Pajarinen, M. (2013). The role of business subsidies in job creation of start-ups, gazelles and incumbents. Small Business Economics, 41(1), 195-214. doi:10.1007/s11187-012-9420-5

LEE, D. S., \& Lemieux, T. (2010). Regression Discontinuity Designs in Economics. Journal of Economic Literature, 48, 281-355.

DINÂMIA'CET - IUL, Centro de Estudos sobre a Mudança Socioeconómica e o Território 
OLSEN, K. M., Kalleberg, A. L., \& Nesheim, T. (2010). Perceived job quality in the United States, Great Britain, Norway and West Germany, 1989-2005. European Journal of Industrial Relations, 16(3), 221240.

SIANESI, B. (2004). An evaluation of the Swedish system of labor market programs in the 1990s. The Review of Economics and Statistics, 86(1), 133-155.

WARR, P. B. (1999). Well-being and the workplace. In Well-being: The foundations of hedonic psychology (pp. 392-412). New York: Russell Sage Foundation.

WORLD BANK (2013). World Development Report: Jobs. Washington: The World Bank. 